\title{
Tulane
}

\author{
Tulane Economics Working Paper Series
}

\section{Is the Haig-Simons Standard Dead? The Uneasy Case for a Comprehensive Income Tax}

\author{
James Alm \\ Department of Economics \\ Tulane University \\ jalm@tulane.edu
}

Working Paper 1806

March 2018

\begin{abstract}
Discussions of the "ideal" form of individual income taxation have largely been based on some variant of the standard suggested by Haig (1921) and Simons (1938). This "Haig-Simons" (H-S) standard argues that an ideal income tax should be imposed on "comprehensive income", and the H-S standard has been used to justify the frequently heard call for a "Broad-based, Low-rate" tax reform strategy. However, I argue in this paper that a truly comprehensive individual income tax has in fact never been fully applied, either in the design of a new income tax or in the reform of an existing one. Indeed, my first conclusion is that the H-S standard is effectively "dead" in terms of its actual real-world relevance to income tax design or reform. This conclusion obviously does not demonstrate that the H-S standard should be discarded as the basis for an ideal individual income tax, including any reform of the income tax. However, my second conclusion is that the "death" of the $\mathrm{H}-\mathrm{S}$ standard is entirely appropriate; that is, there are compelling arguments that can be made for an individual income tax that is in fact imposed on an even narrower tax base, with even more extensive use of the many exclusions, adjustments, deductions, and exemptions that currently populate most all income taxes. Even so, my final conclusion is that there is no one-size-fits-all income tax standard; that is, any standard must consider the specifics of the current environment, especially the underlying goals of taxation.
\end{abstract}

Keywords: Haig-Simons standard; comprehensive income; broad-based, low-rate taxation; tax reform; optimal taxation.

JEL codes: H2, H7. 


\title{
IS THE HAIG-SIMONS STANDARD DEAD? The UneAsy CASE FOR A COMPREHENSIVE INCOME TAX
}

\author{
James Alm*
}

\begin{abstract}
:
Discussions of the "ideal" form of individual income taxation have largely been based on some variant of the standard suggested by Haig (1921) and Simons (1938). This "Haig-Simons" (H-S) standard argues that an ideal income tax should be imposed on "comprehensive income", and the $\mathrm{H}-\mathrm{S}$ standard has been used to justify the frequently heard call for a "Broad-based, Low-rate" tax reform strategy. However, I argue in this paper that a truly comprehensive individual income tax has in fact never been fully applied, either in the design of a new income tax or in the reform of an existing one. Indeed, my first conclusion is that the H-S standard is effectively "dead" in terms of its actual real-world relevance to income tax design or reform. This conclusion obviously does not demonstrate that the H-S standard should be discarded as the basis for an ideal individual income tax, including any reform of the income tax. However, my second conclusion is that the "death" of the H-S standard is entirely appropriate; that is, there are compelling arguments that can be made for an individual income tax that is in fact imposed on an even narrower tax base, with even more extensive use of the many exclusions, adjustments, deductions, and exemptions that currently populate most all income taxes. Even so, my final conclusion is that there is no one-size-fits-all income tax standard; that is, any standard must consider the specifics of the current environment, especially the underlying goals of taxation.
\end{abstract}

Keywords: Haig-Simons standard; comprehensive income; broad-based, low-rate taxation; tax reform; optimal taxation.

JEL Codes: H2, H7.

\footnotetext{
* Tulane University, 6823 St. Charles Avenue, New Orleans, LA 70118 (phone +1 504862 8344; fax +1 504865 5869; email jalm@tulane.edu ).
} 


\section{$\underline{\text { 1. Introduction }}$}

For much of the last century, discussions of the "ideal" form of individual income taxation have largely been based on some variant of the standard suggested by Haig (1921) and Simons (1938). ${ }^{1}$ This "Haig-Simons" (H-S) standard argues that an ideal income tax should be imposed on "comprehensive income", or a measure that includes all sources of real income net of the expenses of earning the income, whether the income is realized or accrued, whether it is cash or in-kind, whether it is earned income or transfer income, and whether it is domestic or foreign generated. In practice, the $\mathrm{H}-\mathrm{S}$ standard plays an especially important role in tax reform discussions, as reflected in the frequently heard call for a "Broad-based, Low-rate" (BBLR) tax reform strategy, in which the income tax base is broadened by eliminating exclusions, adjustments, deductions, exemptions, and other tax preferences, in exchange for which marginal tax rates are imposed at lower rates on the now broader tax base. It is, I believe, fair to characterize most recent proposed and enacted income tax reforms around the world as inspired by the H-S standard. ${ }^{2}$ Indeed, I believe that it is also fair to characterize most all reforms of all taxes, whether of the individual income tax, the corporate income tax, sales and excise taxes, property taxes, or wealth taxes, as largely consistent with the H-S standard of a broad-based, low-rate approach. ${ }^{3}$

\footnotetext{
${ }^{1}$ In fact, the same definition of income was also suggested much earlier by Schanz (1896), and so the correct and complete reference should actually be to the Schanz-Haig-Simons standard. However, since the Haig (1921) and Simons (1938) discussions are more familiar to modern readers, I use only the Haig-Simons (H-S) reference.

${ }^{2}$ The Tax Reform Act of 1986 is probably the most prominent illustration of the BBLR strategy; see the fascinating discussion by one of its architects, C. Eugene Steuerle (Steuerle, 1992, 2004). More recently, one of the proposals of President George W. Bush's Advisory Panel on Federal Tax Reform (“The Simplified Income Tax Plan") was generally consistent with the BBLR strategy (Report of the President's Advisory Panel on Tax Reform, 2005). An even more recent example is the detailed tax reform proposal introduced in the U.S. Congress in February 2014 by Dave Camp, who was at the time Chair of the House Ways and Means Committee as Representative of Michigan's $4^{\text {th }}$ Congressional District. For examples in other countries, see Gillis (1989), Boskin and McLure (1990), The World Bank (1991), Alm, Martinez-Vazquez, and Rider (2006), and Alm and Martinez-Vazquez (2015).

${ }^{3}$ Note that there are important differences between "tax design" (or devising a completely new tax system, without the constraint of an existing tax system) and "tax reform" (or changing an existing tax system). For still useful
} 
The arguments underlying the H-S standard are simple and appealing, based on the underlying taxation goals of equity, efficiency, and adequacy. As discussed in more detail later, the arguments generally proceed in the following manner. First, a tax base that includes all sources of income will, it is argued, treat individuals with different sources of income but with equal amounts of income equally, and so will achieve Horizontal Equity. Similarly, a tax base that includes all sources of income will allow individuals with different incomes to be treated in an appropriately differentiated manner, thereby achieving Vertical Equity. A tax base that includes all sources of income will give individuals little incentive to shift income from one form into another lower taxed form, and so will help meet the Efficiency goal. A broader tax base will generate higher levels of revenues for given tax rates than a narrower tax base, thereby achieving Adequacy. If desired; a broader tax base can instead raise the same revenues with lower tax rates, and a lower tax rate imposed on a larger tax base will also lower the efficiency cost of taxation. There are also political considerations that favor the H-S standard: if it is well-known and widely accepted that all sources of income are to be taxed equally, then it is easier for politicians to say "no" to special interests arguing for special treatments.

However, despite these positive and normative appeals of the H-S standard, a truly comprehensive individual income tax has in fact never been fully applied, either in the design of a new income tax or in the reform of an existing one. Indeed, my first conclusion is that the $H-S$ standard is effectively "dead" in terms of its actual real-world relevance to income tax design or reform: despite the frequent invocations for a BBLR tax system, there are no individual income taxes that come anywhere close to a H-S standard, including (especially) the U.S. income tax. This conclusion obviously does not demonstrate that the H-S standard should be discarded as the 
basis for an ideal individual income tax, including any reform of the income tax. However, perhaps of more note, my second conclusion is that the "death" of the H-S standard is entirely appropriate; that is, there are compelling arguments that can be made for an individual income tax that is in fact imposed on an even narrower tax base, with even more extensive use of the many exclusions, adjustments, deductions, and exemptions that currently populate most all income taxes. Even so, my final conclusion is that there is no one-size-fits-all income tax standard; that is, any standard must consider the specifics of the current environment, especially the underlying goals of taxation.

In the next section I discuss the H-S standard, including the arguments in favor of it in the design or the reform of the individual income tax. I then illustrate the many ways in which actual real-world income taxes diverge from the H-S standard, focusing on the U.S individual income tax as the main example. I then argue that an "optimal" individual income tax should make even greater use of the various tax preferences that are possible, in order to better achieve the goals of equity, efficiency, and adequacy. In the final section I conclude.

\section{Understanding the Haig-Simons Standard of Individual Income Taxation}

Haig (1921) and Simons (1938) originally proposed their respective if related standards largely in the context of the "appropriate" definition of taxable income. Haig (1921, p. 7) wrote that "[i]ncome is the money value of the net accretion to one's economic power between two points of time". Similarly, Simons (1938, p. 50) wrote that income for tax purposes was “...the algebraic sum of the market value of rights exercise in consumption and the change in the value of the store of property rights between the beginning and end of the period in question". In both 
cases, the resulting Haig-Simons standard is an accretion standard, which can be represented by the simple (and somewhat tautological) formula:

$$
I=C+\Delta W
$$

where $I$ is income, $C$ is consumption, $W$ is net wealth, and $\Delta$ denotes a change. Since the change in net wealth $\Delta W$ is equivalent to savings $S$, equation (1) essentially measures income in terms of the uses of income, or $I=C+S$. It is also possible to define income in terms of the sources of income, or:

$$
I=(\text { Gross Earnings }- \text { Expenses })+\text { Transfers }+ \text { Capital Gains } .
$$

$\mathrm{H}-\mathrm{S}$ income, or Comprehensive Income, is therefore best measured as the increase in an individual's potential power to consume over the relevant period, whether the consumption is actually undertaken or not. There are of course many other possible definitions of "income". ${ }^{4}$

So what should be included in the H-S standard? Some obvious distinctions follow immediately from the definitions in equation (1) and in equation (2). Clearly, income is meant to be income net of the expenses of earning income, since it is only net income that increases the power to consume. For similar reasons, income must reflect any changes in prices since nominal changes in income accompanied by equal proportional changes in prices do not change one's ability to consume.

More meaningful distinctions are less obvious. Income does not have to be realized in order for it to increase an individual's ability to consume. An increase in, say, the value of one's stock ownership increases one's ability to consume regardless of whether the capital gain is realized or not. Also, income does not have to be received in the form of cash to be included in comprehensive income, since in-kind income increases an individual's ability to consume. An

\footnotetext{
${ }^{4}$ For a still useful discussion, see Goode (1976), especially Chapter Two. See also Pechman (1977).
} 
especially important form of in-kind income is imputed income, such as imputed income that accrues to homeowners on the basis of their home equity; another important form of in-kind income is an employer's contributions to employee pension and insurance plans. The popular distinction between "earned" and "unearned" income is irrelevant to the H-S definition, since any form of income increases one's ability to consume. For example, government transfer payments, gifts and bequests, alimony, and such should all be included. Similarly, income that is generated either from domestic sources or from foreign sources should be included; that is, the H-S definition is a global measure of one's income.

The resulting measure of comprehensive income, taxable under the H-S standard, would therefore include any and all: (real) wages and salaries, interest income, rental income, profit income, in-kind income (e.g., net imputed rental income, employer contributions to pensions and insurance plans), government transfer payments, gifts and bequests, alimony, and capital gains whether realized or not, less any expenses of earning these incomes.

There are of course many other issues that any individual income tax must also consider, such as the time period that is used to measure income (e.g., annual income versus lifetime income), the unit of taxation (e.g., the individual versus the family), and the rate structure of the tax (e.g., regressive versus proportional versus progressive taxation). Even so, the definition of the base of the tax is an essential first step.

Haig (1921) and Simons (1938) generally intended their definition as a practical and positive way of designing an individual income tax. However, the H-S standard has since become invoked in many settings as a normative criterion, in large part because the H-S notion of income came to be seen as the best measure of an individual's Ability to Pay. Of course, there 
are other normative criteria that we wish a tax (or a tax system) to achieve. How does the H-S standard measure along these criteria?

A "good" tax is designed to achieve multiple objectives. An obvious purpose is to raise the revenues necessary to finance government expenditures (sometimes termed Adequacy), and also to ensure that the growth in revenues is adequate to meet expenditure requirements (Elasticity or Flexibility). Another is to distribute the burden of taxation in a way that meets with a society's notions of fairness (Equity) typically defined in terms of Ability to Pay, such that those with equal ability should pay equal taxes (Horizontal Equity) and those with greater ability should pay greater taxes (Vertical Equity). Taxes can also be used to influence behavior of those who pay them, and a common goal is to minimize the interference of taxes in the economic decisions of individuals and firms (Efficiency or Neutrality). Taxes should be simple, both to administer and to comply with because a complicated tax system wastes the resources of tax administrators and taxpayers (Simplicity). Taxes also need to be politically viable (or Acceptability), and they need to achieve macroeconomic goals as defined by the Musgrave (1959) Stabilization function of government. Overall, as I have argued elsewhere (Alm, 1996), most of these criteria can be usefully collapsed into the three main goals of adequacy, equity, and efficiency. ${ }^{5}$

The H-S standard clearly meets, and easily so, the goal of adequacy. ${ }^{6}$ For any given tax rate (or tax rate structure), a tax base that includes all sources of income will generate more revenues than a more narrowly defined tax base. Alternatively, the broader H-S tax base will raise any given level of tax revenues with a lower tax rate. As discussed later, these conclusions

\footnotetext{
${ }^{5}$ For excellent comprehensive analyses and discussions of many issues in taxation, see Kaplow (2008), Salanie (2011), and Slemrod and Gillitzer (2014).

${ }^{6}$ See Fullerton (1982) for analysis of the static revenue effects of taxation, and Agell and Persson (2001) for similar discussion of the dynamic revenue effects.
} 
may not necessarily hold in a dynamic setting, when consumption-savings decisions are considered. The elasticity of a comprehensive income tax base relative to taxes that utilize alternative definitions of income (or consumption) is also uncertain. Even so, these conclusions seem uncontroversial in a purely static framework.

The H-S standard also largely meets the goal of efficiency, at least in the absence of other types of efficiency considerations like externalities, public goods, and asymmetric information, as discussed later. ${ }^{7}$ When a tax leads individuals to change their decisions solely because of the existence of the tax, then the tax is generates an efficiency cost, or an excess burden. In this regard, any typical individual income tax - including an income tax based on the H-S definition of income - will create multiple distortions along multiple dimensions of behavior. The existence of a marginal tax rate that reduces the return to work or the return to savings will reduce discourage work effort or savings, under plausible conditions on preferences. The existence of tax preferences that reduce the relative cost of, say, charitable donations will encourage donations. There is an enormous amount of research in the last 50 years that demonstrates the distorting effects of the individual income tax on behavior in such dimensions as labor supply, savings, charitable donations, capital gains realizations, compensation choice, housing, health insurance, tax shelters, tax evasion, and income reporting, to name only a few such dimensions. These studies generally find that individuals respond in significant ways to changes in the individual income tax, especially to marginal tax rate changes, although there is much debate on whether these responses represent changes in real behavior or simply changes in either the timing or the financial form of transactions. ${ }^{8}$

\footnotetext{
${ }^{7}$ See Auerbach (1985) and Auerbach and Hines (2002) for detailed discussions of efficient taxation.

${ }^{8}$ The empirical literature on the distorting effects of taxation is enormous, and ever-growing. For selective surveys of much of this literature, surveys that also demonstrate the evolving methods of empirical analyses over time, see Slemrod (1992), Auerbach and Slemrod (1997), and Saez, Slemrod, and Giertz (2012).
} 
An individual income tax that utilizes the H-S standard is not immune to these distorting effects. Even so, I believe that it is plausible that the distorting effects of a comprehensive income tax are smaller than those of the typical income tax. If an individual income tax base included all forms of income and made no special allowances for certain types of discretionary spending, there would be virtually no incentive for an individual to make charitable donations; to change the realization of capital gains by the sale of assets; to get more of their income in fringe benefits versus wages versus capital income versus tax shelters; to change housing decisions between owner-occupied versus rental housing; and so on. It is when different forms of income are treated differently by the income tax, or when different forms of spending are treated differently, that the distorting effects of the tax on behavior are most felt. To be sure, even the HS standard will distort decisions like labor supply, savings, or tax evasion. Further, it is wellknown that, in a second-best world, it is impossible to say with certainty that these distorting effects will be smaller under the H-S standard than under alternative measures of income. However, the H-S standard clearly reduces the margins of behavioral response relative to alternative tax bases. As a result, it is certainly plausible to argue that the H-S individual income tax will generate a smaller excess burden of taxation than these alternative taxes. The likelihood that the broader base of a comprehensive individual income tax will allow the use of a lower marginal tax rate to generate any given level of tax revenues also suggests that the efficiency cost of the H-S standard will be lower than other taxes, given that excess burden increases with the (square of the) tax rate.

As for equity concerns, a tax base that includes all sources of income will treat individuals with different sources of income but with equal amounts of income equally, thereby achieving horizontal equity. Under the typical individual income tax in which wage income is 
fully taxable but, say, employer-provided health insurance is not taxable, two individuals who have equal H-S income but who receive their compensation in forms that are treated differently by the income tax will pay different amounts of income taxes. Similarly, under the typical individual income tax, an individual who owns his or her own home will pay less in income taxes than an otherwise identical individual who rents; an individual who sells an asset for realized capital gains will pay more in taxes than an identical individual who does not sell an equally valued asset; an individual who receives interest income from a fully taxable financial institution will pay more in taxes than an identical individual who receives an equal amount of interest income from non-taxable state and local bonds; and so on. Similar considerations apply to vertical equity. It should not matter for vertical equity whether an individual receives income in tax-favored versus tax-penalized forms. Rather, all that matters for the appropriate treatment of unequals is the total amount of their incomes, regardless of the specific forms in which these incomes are received. A tax base that includes all sources of income will allow individuals with different incomes to be treated in an appropriately differentiated manner, according to the specific form of vertical equity that informs tax policies. ${ }^{9}$

The appeal of the H-S standard is, I believe, understandable. However, as I discuss next, this standard has in fact never been really used anywhere, especially in the United States.

\section{Real-world Departures from the Haig-Simons Standard}

The typical individual income tax base that is in place in countries around the world vastly differs from the H-S standard. Consider the United States as the illustrative example. On a practical level, the steps involved in calculating "Taxable Income" in the individual income tax

\footnotetext{
${ }^{9}$ See Musgrave (1976), Kaplow (1989), and Young (1990) for insightful discussions of equitable taxation.
} 
are in principle straightforward. Using the 2016 Internal Revenue Service (IRS) Form 1040 as a reference, these steps are as follows:

- Add all taxable forms of income (e.g., wages, salaries, tips, taxable interest, dividends, alimony received, business income, capital gains, individual retirement account distributions, pensions and annuities, rental real estate, royalties, partnerships, farm income, unemployment compensation, social security benefits) on lines 7 to 21 of Form 1040 to generate Total Income (or Gross Income) on line 22;

- Subtract various allowed items (or Adjustments) on lines 23 to 35 of Form 1040 to generate Adjusted Gross Income on line 37, including such items as educator expenses, business expenses, health savings accounts, moving expenses, various selfemployment payments, alimony paid, individual retirement account deduction, and student loan interest;

- Subtract Deductions, either a standard deduction or itemized deductions (line 40) and Exemptions (line 42) to generate Taxable Income on line 43;

- Calculate the Tax that is payable on line 44 , as modified by several additional considerations on lines 45 to $62 .{ }^{10}$

The Total Tax payable is determined on line 63. There are also several computations involved in making Payments (lines 64 to 74) and Refund (lines 75 to 77), before calculating the Amount You Owe (line 78). ${ }^{11}$ An especially prominent tax credit is the Earned Income Credit (line 66).

On a more conceptual level, one can progress from H-S comprehensive income to Form

1040 Taxable Income by a slightly different procedure, one that illustrates more clearly the specific ways in which H-S income differs from income actually subject to the income tax.

Starting with comprehensive income, then:

- Subtract income that is illegally excluded (e.g., Evasion) from comprehensive income;

- Subtract Exclusions, or income that is legally excluded from individual income tax base. Exclusions encompass many of the myriad and legal ways in which H-S income diverges from Form 1040 Taxable Income. For example, employer contributions to pensions and insurance plans, many government transfer payments, interest paid by state and local governments, net imputed rental income, and any unrealized capital gains are legally excluded. The resulting income measure is Gross Income (or line 22 on Form 1040);

\footnotetext{
${ }^{10}$ These additional considerations include the alternative minimum tax, various tax credits, and several additional taxes.

${ }^{11}$ The specific steps that are involved in these calculations have of course changed over time, as the individual income tax has changed over time.
} 
- Subtract Adjustments (or lines 23 to 35 of Form 1040) from Gross Income to get Adjusted Gross Income (or line 37 on Form 1040);

- Subtract Deductions (line 40) and Exemptions (line 42) to generate Taxable Income (line 43);

- Calculate the Tax that is payable (line 44 ), as modified by several additional considerations (lines 45 to 62 ).

The end points (or Taxable Income, Tax, Total Tax, Payments, Refund, and Amount You Owe) are of course identical in either approach.

Aside from Evasion, it is mainly through these Exclusions, Adjustments, Deductions, and Exemptions that the H-S standard of comprehensive income differs from the Taxable Income that shows up on line 43 of Form 1040; the uses of various Tax Credits also leads to a divergence between H-S income and Taxable Income. Indeed, the total amount of these various leakages, sometimes referred to as Tax Expenditures, is enormous. ${ }^{12}$ In the most recent estimates from the U.S. Department of the Treasury, Office of Tax Policy (2016), the three largest of the tax expenditures for the individual income tax in fiscal year (FY) 2018 are estimated to be the exclusion of employer contributions for medical insurance and medical care, the exclusion of net imputed rental income, and preferential treatment of capital gains. ${ }^{13}$ There are similar if

12 The term Tax Expenditures is due to Stanley Surrey in 1967, when he was serving as Assistant Secretary of the Treasury for Tax Policy. See especially Surrey (1973) for a detailed discussion on the concept.

${ }^{13}$ The major tax expenditures in the individual income tax in FY 2018 are estimated by the U.S. Department of the Treasury, Office of Tax Policy (2016) as:

\begin{tabular}{|l|c|}
\hline Item & $\begin{array}{c}\text { Amount } \\
\text { (\$ billions) }\end{array}$ \\
\hline Exclusion of employer contributions for medical insurance and medical care & $\$ 235.8$ \\
\hline Exclusion of net imputed rental income & 112.7 \\
\hline Capital gains (except agriculture, timer, iron ore, and coal) & 108.6 \\
\hline Defined benefit employer plans & 71.0 \\
\hline Defined contribution employer plans & 69.4 \\
\hline Deductibility of mortgage interest on owner-occupied homes & 68.1 \\
\hline Deductibility of nonbusiness state and local taxes other than on owner-occupied homes & 63.3 \\
\hline Step-up basis of capital gains at death & 54.1 \\
\hline Deductibility of charitable contributions, other than education and health & 51.2 \\
\hline Capital gains exclusion on home sales & 48.5 \\
\hline Social security benefits for retired and disabled workers and spouses, dependents, and survivors & 40.6 \\
\hline Deductibility of state and local property tax on owner-occupied homes & 38.9 \\
\hline Self-employed plans & 33.8 \\
\hline
\end{tabular}


somewhat smaller tax expenditures for the corporate income tax, for which the single largest item in FY 2018 is the deferral of income from controlled foreign corporations ( $\$ 112.5$ billion). Total tax expenditures for individuals and corporations are estimated to exceed $\$ 1.5$ trillion in FY 2018 for the 167 specific tax expenditure items.

The U.S. is hardly an outlier, as demonstrated in a number of studies. For example, various publications of PricewaterhouseCoopers $(\mathrm{PwC})$, working with The World Bank Group, on worldwide tax summaries demonstrate clearly the departure from the H-S standard in realworld tax systems. ${ }^{14}$ Also, the Organisation for Economic Co-operation and Development (OECD) compiles detailed information on the taxation of individuals, mainly but not exclusively for OECD countries, which also shows the myriad ways in which the taxation of individuals differs from the H-S standard. ${ }^{15}$

So my first conclusion is that the H-S standard is effectively "dead" in terms of its actual real-world relevance to income tax design or reform. The individual income tax in the U.S. is far from the H-S standard, and the U.S. is representative of most other countries in departures from the H-S standard. In short, there are no individual income taxes that come anywhere close to a HS standard.

\footnotetext{
Exclusion of interest on public purpose state and local bonds Treatment of qualified dividends Source: U.S. Department of the Treasury, Office of Tax Policy (2016).

14 The most recent PwC publication is for 2017, available online at http://www.pwc.com/gx/en/payingtaxes/pdf/pwc-paying-taxes-2017.pdf.

15 The most recent OECD publication is for 2017, online at http://www.oecdilibrary.org/docserver/download $/ 2317021$ e.pdf?expires $=1502289791 \& \mathrm{did}=\mathrm{id} \&$ accname $=$ ocid45123324\&checksum $=$ FAC2A72A503E5638D23CA89E34205C9E. The OECD also compiles information on various administrative dimensions of individual (and corporate) income taxes; the most recent publication for 2015 is available at http://www.oecdilibrary.org/docserver/download/2315111e.pdf?expires $=1502289043 \& \mathrm{id}=\mathrm{id} \&$ accname $=$ ocid $45123324 \& \mathrm{checksum}=$ 4D2B66C9E8A5376B600922742B76E887.
} 


\section{Reasons for Departures from the Haig-Simons Standard}

Of course, the supposed "death" of the H-S standard in its actual application to real-world tax policy obviously does not demonstrate that the H-S standard should be abandoned as the basis for an ideal individual income tax. However, as I argue next, the "death" of the H-S standard is entirely appropriate; that is, there are compelling arguments that can be made for an individual income tax that is in fact imposed on an even narrower tax base, with even more extensive use of the many exclusions, adjustments, deductions, and exemptions that currently populate most all income taxes.

Indeed, I believe that there are many convincing rationales for departures from the $\mathrm{H}-\mathrm{S}$ standard of comprehensive income. In some cases, the motivation is no doubt political, and I do not discuss this consideration. ${ }^{16}$ However, there are also compelling reasons for departures based on equity, efficiency, and even adequacy considerations.

Consider these various departures. They fall into several main categories: those designed to align a taxpayer's income with the taxpayer's ability to pay, including adjustments designed to define more accurately income as a measure of ability to pay; those designed to encourage certain forms of expenditures due to various efficiency considerations; those designed to reduce administrative burdens, again due to efficiency considerations.

For equity reasons, we make selective use of exemptions, deductions, and credits, mainly to allow tax liabilities to be adjusted more precisely to individual circumstances. The most prominent example here, I believe, is the use of personal exemptions, which eliminate from taxation an amount of income thought necessary to maintain a minimum standard of living. In the absence of a personal exemption, an individual (or a family) with income below the threshold

\footnotetext{
${ }^{16}$ See Hettich and Winer (1988) and Kenny and Winer (2006) for analyses of some political aspects of tax design.
} 
of the specified exemption level would be unduly burdened by having to pay income taxes. This reasoning suggests that the number of exemptions should vary with the number of family members. It also suggests that the form of relief should be given as a deduction rather than as a credit because the exemption is necessary to better measure the taxpayer's ability to pay and so the value of the exemption to the taxpayer should not depend upon the taxpayer's marginal tax rate. For similar reasons, there are also special exemptions for taxpayers who are older, blind, or disabled.

A related equity consideration is the adjustment of comprehensive income to better measure a taxpayer's ability to pay. Large, unexpected, and non-routine expenditures reduce an individual's ability to pay, and so these expenditures should appropriately be subtracted from income. These types of expenditures include such items as medical expenditures and property losses, typically and properly treated as an allowable deduction from income. This treatment is not without some controversy. To the extent that an individual has discretion over medical expenditures or even over property losses, then these types of deductions represent voluntary consumption expenditures, which should be included in H-S income. A similar reasoning suggests that the case for state and local tax payments as an allowable deduction from $\mathrm{H}-\mathrm{S}$ income is weak. These tax payments may simply reflect the discretionary decision of an individual to live in a jurisdiction with more government services financed by higher taxes, so that the higher tax payments may again reflect greater voluntary consumption expenditures, as suggested by a Tiebout-type equilibrium.

The costs of earning income should also be allowed as a deduction from gross income, since H-S income is meant to measure one's ability to consume and any costs of earning income do not increase one's ability to consume; that is, comprehensive income is a net income standard. 
For example, the costs of maintaining a business office, traveling for business, or purchasing a uniform required for work are properly viewed as necessary business expenses, which should therefore be deducted from H-S income as an expense of earning income. While this practice may seem straightforward, even here there are difficulties in defining legitimate business expenses. The costs of maintaining a business office likely require, say, the purchase of a desk, but does the allowable business expense include the price of an antique desk or only the minimum price necessary for a desk? Likewise, do the costs of traveling for business include commuting expenses when the individual has voluntarily chosen to live in a location that requires large travel expenses, or traveling in first-class accommodations when cheaper methods are available? Similar issues arise for childcare expenses, business entertainment expenses, educational/training expenses, clothing expenses, and the like. Any expense that represents a voluntary consumption expenditure rather than a business-related expense should properly be included in H-S income.

Overall, these types of issues indicate that equal H-S income across individuals may not in fact imply equal ability to pay for these taxpayers (horizontal equity), or that unequal H-S income may not imply differential tax treatment (vertical equity). These issues need to be considered in the equitable design of individual income taxes, in order to better adjust income taxes to specific individual circumstances.

For efficiency reasons, we often diverge from the H-S standard by excluding a specific tax base that theory suggests should be taxed, on the grounds that it is administratively costly to tax (e.g., imputed rental income, unrealized capital gains, in-kind income). Perhaps a more compelling efficiency reason is that market provision of certain types of goods and services may be inefficient due to the presence of externalities, public goods, or asymmetric information 
considerations. In these cases, favorable income tax treatment may lead to efficiency gains, even if this favorable tax treatment is otherwise inconsistent with the H-S standard.

A prominent example of this favorable tax treatment is the tax deduction for charitable donations. If charitable organizations provide goods and services that generate positive externalities or that have public good characteristics (e.g., nonrival and nonexclusive), then private markets will provide inefficiently low levels of these goods and services. In this case, favorable tax treatment via tax deductibility may help achieve efficient levels, even at the cost of violating the H-S standard. Of course, there are other means by which government can encourage efficient provision, notably by direct government provision of the relevant activity. Even so, as demonstrated by Feldstein (1980), there are circumstances under which provision via individual income tax provisions is the more efficient mechanism. If direct government provision crowds out private actions while a tax subsidy crowds in private contributions, then a tax subsidy may be able to achieve efficient provision with smaller resource costs. Similar (if weaker) arguments may justify tax preferences: for housing (e.g., the deduction for mortgage interest, the exclusion of net imputed rental income, the deduction for property taxes) given the positive externality and/or public good aspects of owner-occupied housing; for educational expenses (again given the positive externality and/or public good aspects of education); for health-related expenditures (given the asymmetric information problems that are often present); and the like.

A somewhat different efficiency argument invokes dynamic efficiency considerations. It is widely recognized that the individual income tax has significant and negative effects on savings. ${ }^{17}$ An income tax leads to "double taxation" of income, when the income is earned as wages and when any interest income is received. This double taxation clearly reduces the return

\footnotetext{
${ }^{17}$ This literature is enormous. For a recent excellent discussion of the dynamic aspects of taxation, see Kocherlakota (2010).
} 
to saving, thereby creating a dynamic inefficiency through lower capital formation and so lower economic growth. It is in part because of concern that the individual income tax generates too little saving (and so too much consumption) that nearly all proposals for fundamental tax reform seek to replace the income tax with some form of consumption tax. ${ }^{18}$

This reasoning also justifies on dynamic efficiency grounds low (perhaps zero) tax rates on capital income (including capital gains), as well as low (perhaps zero or even negative) tax rates on gifts and bequests, all in an attempt to encourage more savings and so higher economic growth. ${ }^{19}$ These favorable tax treatments may be given as exclusions: of some forms of interest income (e.g., from state and local government bonds); of realized or unrealized capital gains income (including tax loss offsets, the step-up basis at death, the exclusion of capital gains on housing, the treatment of "carried interest"); of various forms of retirement income; of various types of savings instruments and financial assets (e.g., individual retirement accounts (IRAs), Roth IRAs, 401(k) accounts, Keogh accounts for self-employed taxpayers); and of gifts and bequests income. They may also be given either as adjustments (e.g., for specified forms of savings) or as deductions (e.g., for some forms of interest paid on borrowed funds). By removing savings from the base of individual income tax, these favorable tax treatments effectively transform the income tax to a consumption tax.

One last type of efficiency argument for divergence from the H-S standard relates to administrative difficulties in measuring some forms of comprehensive income. The measurement

\footnotetext{
${ }^{18}$ There are also various arguments for a consumption tax that are based on equity considerations. One argument attributed to Thomas Hobbes is that "... it is fairer to tax people on what they extract from the economy...than to tax them on what they produce for the economy". Another related argument is that consumption is a better measure than income of underlying utility, especially over one's lifetime. There are of course counterarguments based on equity considerations, especially the likely regressivity of a consumption tax. For various discussions on consumption (and other) taxes, see Pechman (1980), Auerbach (2006), and Slemrod and Bakija (2017). For a classic and still useful discussion, see U.S. Department of the Treasury (1977).

${ }^{19}$ For example, see Auerbach and Kotlikoff (1987) and Judd (1999).
} 
of net imputed rental income may well be difficult and costly, and there are other types of imputed income (e.g., consumer durables) that are also difficult to measure. The measurement of in-kind income, such as food consumed on farms, is problematic, as is the measurement of the value of own-provided personal services; these latter forms of H-S income are also likely to be of negligible value, at least in the U.S.

Overall, these types of issues indicate that a "level playing field" across H-S income sources does not in fact lead to efficient taxation of these income sources. Rather, there are compelling efficiency reasons for differential taxation, via exclusions, adjustments, deductions, and exemptions. Again, these issues need to be considered in the efficient design of individual income taxes.

Perhaps surprisingly, there may even be some adequacy justifications for diverging from the H-S standard. If some forms of income are relatively unresponsive to tax rate changes, even if they do not truly represent H-S income, then their taxation will generate greater amounts of revenues.

These considerations also have implications for the tax rates that should be imposed on $\mathrm{H}-\mathrm{S}$ income. There is often the presumption that low and uniform tax rates should be used, as reflected in the BBLR prescription. However, there are also compelling reasons for diverging from the low and uniform tax rate standard. For equity reasons, we may tax some activities at higher (or lower) rates than other activities, rather than at uniform rates, because differential taxation may allow equity gains if the pattern of consumption differs systematically by income. ${ }^{20}$ For efficiency reasons, we may tax some activities at higher (or lower rates) than other activities. For example, as noted earlier, activities that generate positive externalities should receive

\footnotetext{
${ }^{20}$ See Diamond (1975).
} 
favorable tax treatment, including the possibility of subsidies (e.g., charitable donations, housing, education, health, capital income, gifts and bequests), and activities that generate negative externalities should be taxed (e.g., cigarettes, alcohol, gasoline). Also, activities that are less responsive to taxes should be taxed more heavily, as suggested by Ramsey Rule considerations. ${ }^{21}$ For adequacy reasons, activities that are less responsive to taxes should be taxed at higher rates than activities that are more responsive (e.g., primary earners versus secondary earners).

In fact, if the use of lower tax rates on some individuals or activities is justified by equity, efficiency, or adequacy considerations, then it is necessary to impose higher tax rates on other individuals or activities to achieve these goals. On this basis, a tax base that diverges in significant ways from the H-S standard may actually offer a greater opportunity to impose a differentiated tax rate structure, including the use of progressive tax rates. Also, the use of progressive tax rates clearly allows tax liabilities to reflect more precisely vertical equity considerations by imposing higher (lower) tax rates on those with greater (lower) ability to pay.

Now it is no doubt the case that the design and reform of taxes is not always grounded in purely economic arguments, and political considerations necessarily enter the calculus of politicians in deciding to diverge from the H-S standard. Even so, I believe that there are many compelling equity, efficiency, and adequacy reasons for an individual income tax that diverges from a broad-based, low-rate design. Indeed, this reasoning suggest that the BBLR standard for other taxes - especially corporate income taxes, general sales taxes, excise taxes, property taxes, and gift and estate taxes - may also be misguided in at least some circumstances. Along these lines, there are many taxes that meet the broad-based, low rate standard that are in fact "bad"

\footnotetext{
${ }^{21}$ Efficient taxation was first examined by Ramsey (1927). It took some time before "Ramsey Rule" considerations made their way into public economics. The modern "optimal taxation" literature began with Diamond and Mirrlees (1971), and Mirrlees (1971), and has continued to grow ever since.
} 
taxes, such as a tax on financial transactions, a turnover tax, or a gross receipts tax. In short, there is nothing magical about the H-S standard as a guide to "ideal" tax policy.

\section{Conclusions}

The Haig-Simons standard is obviously not really dead, and economists - and politicians - will no doubt continue to invoke it, for good and bad reasons. However, I believe that the H-S standard has been modified so extensively in practice that virtually any departure can now be justified. This makes any real-world application very arbitrary. It also makes the case for a comprehensive income tax an "uneasy" one. ${ }^{22}$

So if the H-S standard is no longer all that relevant, what should be the standard? I also believe that a strong case can be made for deviating even more significantly from the H-S standard than current practice suggests. More exclusions/adjustments/deductions/exemptions can make taxes more equitable by more closely aligning taxes with ability to pay. They can also make taxes more efficient - and sometimes more adequate - by taxing more (less) heavily inelastic (elastic) activities, by taxing more (less) heavily activities that generate negative (positive) externalities, and by providing more savings incentives. This is not to suggest that all tax preferences have a justifiable place in an equitable, efficient, and adequate tax system. It is simply to suggest that the H-S standard - or a comprehensive income tax base or a BBLR approach - has many inherent flaws, and that an approach that appropriately applies the many possible tax preferences in a judicious manner can be a far more effective way to design and to reform taxes.

\footnotetext{
${ }^{22}$ The use of "uneasy" here is a deliberate reference to the classic Blum and Kalven (1953) treatise, The Uneasy Case for Progressive Taxation.
} 
Of course, this advice makes the design and reform of taxes more difficult. If the only "rule" for taxation is captured in the H-S standard, then tax policy becomes a straightforward, even an easy, exercise: eliminate all tax preferences and calculate the lowest tax rate necessary to generate the target level of revenues. It is when each possible deviation from the H-S standard requires close examination that tax prescriptions become as much art as science.

In fact, this reasoning leads naturally to the conclusion that the appropriate approach to real-world tax policy must be situation-specific. This approach may well start with the H-S standard. For example, countries with limited tax administration capacity, and so with limited ability to apply effectively tax preferences, may well be best served by applying the BBLR approach, although even in these cases administrative capacity may call for significant deviations from the H-S standard. ${ }^{23}$ However, for most countries the search for an optimal tax design or reform cannot end with the H-S standard. Instead, the search must recognize that departures from the H-S standard are necessary, desirable, and even inevitable. More broadly, the search must also recognize that any advice must be guided by clearly articulated principles based intimately on the specific circumstances being considered.

All of these considerations suggest that a broad-based, low-rate approach may sometimes be the appropriate path for tax design and reform. However, it may also be proper to diverge in significant ways from the BBLR guidelines, depending of course on specific circumstances.

Having said this, I must confess that I myself have often invoked the H-S standard of a broad-based, low-rate tax reform on many of the tax reforms upon which I have worked over the years. Indeed, my recent work with James Richardson and Steven Sheffrin on the Louisiana tax system illustrates these divergences between the H-S/comprehensive income/BBLR mandate and

\footnotetext{
${ }^{23}$ See Martinez-Vazquez and McNab (2000) and Bird (2014) for discussions of tax design and reform in transition and developing countries.
} 
the specific reforms that we recommended. For the individual income tax, we recommended the expansion of the individual income tax base to include some - but not all - deductions and other tax preferences. We also recommended a largely flat rate tax structure for the individual income tax - but with some progressivity. Going beyond the individual income tax, we recommended the expansion of the sales tax base to include some - but not all - services, as well as the elimination of several - but not all - of the development incentives in the corporate income tax base. We even wrote that the guiding principles for constructing a state tax structure "...include broad tax bases allowing for low tax rates". ${ }^{24}$

Indeed, it is unlikely that consensus on an optimal tax system will ever exist. A recent exchange clearly illustrates the conflicting conclusions that even the very best experts can draw about an optimal tax system and optimal tax reform. Mankiw, Weinzierl, and Yagan (2009) concluded that:

- The optimal marginal tax schedule could decline at high incomes.

- A flat tax, with a universal lump-sum transfer, could be close to optimal.

- Capital income ought to be untaxed.

In sharp contrast, Diamond and Saez (2011) concluded, along these exact same dimensions, that:

- Very high earnings should be subject to rising marginal rates and higher rates than current U.S. policy for top earners.

- Tax and transfer policy toward low earners should include subsidization of earnings and should phase out the subsidization at a relatively high rate.

- Capital income should be taxed.

There are profound differences here, even among economists who are looking at the exact same evidence but who are drawing completely opposite conclusions. These conflicting conclusions arise in large part because underlying assumptions and evidence about what is driving these

\footnotetext{
${ }^{24}$ To be clear, my views on the H-S standard are my own, and my colleagues do not necessarily share them. For the full details of our recommendations, see Richardson, Sheffrin, and Alm (2017); the basics of our recommendations are available online at http://murphy.tulane.edu/programs/public-policy/public-finance/louisiana-tax-study.
} 
theories and the resulting recommendations differ, because underlying value judgments also differ, and, especially, because underlying goals differ.

So my third and final conclusion here is a simple and an obvious one: There is no onesize-fits-all income tax standard. Any standard must consider the institutions, the traditions, the economic policies, and the politics of the current situation, any standard must recognize and balance the tradeoffs, and any standard must be guided by the alignment between fundamental principles and underlying goals. All of these considerations will vary according to specific circumstances. Put differently and more broadly, the attempt to reduce complex public policy discussions to "best practices", stated in the form of "general guidelines" or even "universal principles", is fundamentally misguided. Specific conditions differ so profoundly across individuals, firms, markets, countries, and time that most any attempt to define "best practices" that apply in all settings will lead to profoundly misleading public policy recommendations. There are simply too many features that must be known but that are unknown and often unknowable, to implement any "best practices" prescriptions. These difficulties should not discourage the search for, say, specific policies that apply to a specific setting at a specific point in time as based on specific principles and goals. However, such policies will necessarily be couched in the specific circumstances under consideration, and they will be quite unlikely to apply in other settings. Rather, public policies must make intimate connection to the time and institutional settings in which they are employed. In other words, the search for "best practices" should be seen largely as a search for the "Holy Grail" - it is alluring and seductive but ultimately unachievable. The automatic, almost mechanical, injunction of the H-S standard in all matters of tax design and reform surely illustrates the problems that "best practices" policy advice can generate. 


\section{References}

Agell, Jonas, and Mats Persson. 2001. On the analytics of the dynamic Laffer curve. Journal of Monetary Economics, 48 (2): 397-414.

Alm, James. 1996. What is an "optimal" tax system? National Tax Journal, 49 (1): 117-133.

Alm, James, and Jorge Martinez-Vazquez (eds.). 2015. Tax Reform in Developing Countries, Volumes I and II. Cheltenham, UK - Northampton, MA: Edward Elgar Publishing.

Alm, James, Jorge Martinez-Vazquez, and Mark Rider (eds.). 2006. The Challenges of Tax Reform in a Global Economy. Norwell, MA: Springer Science + Business Media, Inc.

Auerbach, Alan J. 1985. The theory of excess burden and optimal taxation. In Handbook of Public Economics, Volume 1, Alan J. Auerbach and Martin Feldstein (eds.). Amsterdam, The Netherlands, London, UK, and New York, NY: Elsevier B.V. North Holland Publishers, 61-127.

Auerbach, Alan J., and Laurence J. Kotlikoff. 1987. Dynamic Fiscal Policy. New York, NY: Cambridge University Press.

Auerbach, Alan J., and Joel Slemrod. 1997. The economic effects of the Tax Reform Act of 1986. The Journal of Economic Literature, 35 (2): 589-632.

Auerbach, Alan J., and James R. Hines, Jr. 2002. Taxation and economic efficiency. In Handbook of Public Economics, Vol. 3, Alan J. Auerbach and Martin Feldstein (eds.). Amsterdam, The Netherlands, London, UK, and New York, NY: Elsevier B.V. North Holland Publishers, 1347-1421.

Bird, Richard M. 2014. Administrative dimensions of tax reform. Annals of Economics and Finance, 15 (2): 963-992.

Blum, Walter J., and Harry Kalven, Jr. 1953. The Uneasy Case for Progressive Taxation. Chicago, IL: The University of Chicago Press.

Diamond, Peter A. 1975. A many-person Ramsey tax rule. Journal of Public Economics, 4 (4): 335-342.

Diamond, Peter A., and James A. Mirrlees. 1971. Optimal taxation and public production, Parts I and II. The American Economic Review, 61 (1): 8-27; and 61 (3, Part 1): 261-278.

Diamond, Peter A., and Emmanuel Saez. 2011. The case for a progressive tax: From basic research to policy recommendations. The Journal of Economic Perspectives, 25 (4): 165190.

Feldstein, Martin S. 1976. On the theory of tax reform. Journal of Public Economics, 6 (1): 77 104.

Feldstein, Martin. 1980. A contribution to the theory of tax expenditures: The case of charitable giving. In The Economics of Taxation, Henry J. Aaron and Michael J. Boskin (eds.). Washington, D.C.: The Brookings Institution, 99-122.

Fullerton, Don. 1982. On the possibility of an inverse relationship between tax rates and tax revenues. Journal of Public Economics, 19 (1): 3-22.

Goode, Richard. 1976. The Individual Income Tax (Revised Edition). Washington, D.C.: The Brookings Institution.

Haig, Robert M. 1921. The concept of income - Economic and legal aspects. In The Federal Income Tax, Robert M. Haig (ed.). New York, NY: Columbia University Press, 1-28. 
Hettich, Walter, and Stanley L. Winer. 1988. Economic and political foundations of tax structure. The American Economic Review, 78 (4): 701-712.

Judd, Kenneth L. 1999. Optimal taxation and spending in general competitive growth models. Journal of Public Economics 71 (1): 1-26.

Kaplow, Louis. 1989. Horizontal equity: Measures in search of a principle. National Tax Journal, 42 (2): 139-154.

Kaplow, Louis. 2008. The Theory of Taxation and Public Economics. Princeton, NJ: Princeton University Press.

Kenny, Lawrence, and Stanley L. Winer. 2006. Tax systems in the world: An empirical investigation into the importance of tax bases, administration costs, scale, and political regime. International Tax and Public Finance, 13 (2): 181-215.

Kocherlakota, Narayana R. 2010. The New Dynamic Public Finance. Princeton, NJ: Princeton University Press.

Mankiw, N. Gregory, Matthew C. Weinzierl, and Danny Yagan. 2009. Optimal taxation in theory and practice. The Journal of Economic Perspectives, 23 (4): 147-174.

Martinez-Vazquez, Jorge, and Robert M. McNab. 2000. The tax reform experiment in transitional countries. National Tax Journal, 53 (2): 273-298.

Mirrlees, James A. 1971. An exploration in the theory of optimal income taxation. Review of Economic Studies, 38 (2): 175-208.

Musgrave, Richard A. 1959. The Theory of Public Finance - A Study in Public Economy. New York, NY: McGraw-Hill Book Company.

Musgrave, Richard A. 1976. ET, OT, and SBT. Journal of Public Economics, 6 (1/2): 3-16.

Pechman, Joseph A. (ed.). 1977. Comprehensive Income Taxation. Washington, D.C.: The Brookings Institution.

Pechman, Joseph A. (ed). 1980. What Should Be Taxed? Income or Expenditure. Washington, D.C.: The Brookings Institution.

Ramsey, Frank P. 1927. A contribution to the theory of taxation. Economic Journal, 37 (145): 47-61.

Report of the President's Advisory Panel on Tax Reform. 2005. Simple, Fair, and Pro-growth: Proposals to Fix America's Tax System. Washington, D.C.: Government Printing Office.

Richardson, James A., Steven M. Sheffrin, and James Alm. 2017. Reforming Louisiana's Tax System. Baton Rouge, LA: Louisiana State University Press.

Saez, Emmanuel, Joel Slemrod, and Seth H. Giertz. 2012. The elasticity of taxable income with respect to marginal tax rates: A critical review. The Journal of Economic Literature, 50 (1): 3-50.

Salanie, Bernard. 2011. The Economics of Taxation. Cambridge, MA: The MIT Press.

Schanz, Georg von. 1896. Der einkommensbegriff und die einkommensteuergesetze [Income realized and the income tax law]. FinanzArchiv, 13 (1): 1-87.

Simons, Henry C. 1938. Personal Income Taxation: The Definition of Income as a Problem of Fiscal Policy. Chicago, IL: University of Chicago Press.

Joel Slemrod (ed.). 1992. Do Taxes Matter? The Impact of the Tax Reform Act of 1986. Cambridge, MA: The MIT Press.

Slemrod, Joel, and Jon Bakija. 2017. Taxing Ourselves: A Citizen's Guide to the Debate over Taxes (Fifth Edition). Cambridge, MA: The MIT Press.

Slemrod, Joel, and Christian Gillitzer. 2014. Tax Systems. Cambridge, MA: The MIT Press.

Steuerle, C. Eugene. 1992. The Tax Decade. Washington, D.C.: The Urban Institute Press. 
Steuerle, C. Eugene. 2004. Contemporary U.S. Tax Policy. Washington, D.C.: The Urban Institute Press

Surrey, Stanley S. 1973. Pathways to Tax Reform: The Concept of Tax Expenditures. Cambridge, MA: Harvard University Press.

U.S. Department of the Treasury. 1977. Blueprints for Basic Tax Reform. Washington, D.C.: U.S. Government Printing Office.

U.S. Department of the Treasury, Office of Tax Policy. 2016. Tax Expenditures. Washington, D.C.: Government Printing Office.

World Bank, The. 1991. Lessons of Tax Reform. Washington, D.C.: The World Bank.

Young, H. Peyton. 1990. Progressive taxation and equal sacrifice. The American Economic Review, 80 (1): 253-266.

Zodrow, George R. 1981. Implementing tax reform. National Tax Journal, 34 (4): 401-418. 